\title{
THREE-DIMENSIONALLY PRESERVED SPECIMENS OF AMPLEXOGRAPTUS (ORDOVICIAN, GRAPTOLITHINA) FROM THE NORTH AMERICAN MID- CONTINENT: TAXONOMIC AND BIOSTRATIGRAPHIC SIGNIFICANCE
}

\author{
DANIEL GOLDMAN, ${ }^{1}$ SHANNON M. CAMPBELL, ${ }^{1}$ AND JEFFREY M. RAHL ${ }^{2}$ \\ ${ }^{1}$ Department of Geology, The University of Dayton, Ohio 45469, <Dan.Goldman@ notes.udayton.edu> \\ ${ }^{2}$ Department of Geology and Geophysics, Yale University, New Haven, Connecticut 06511
}

\section{INTRODUCTION}

GRAPTOLITES ARE relatively uncommon fossils in the Middle and Upper Ordovician carbonates of the North American mid-continent. With the notable exception of the Viola Springs Formation in Oklahoma, most units contain a single species, which occur within narrow stratigraphic intervals (often single beds). While uninteresting in terms of their diversity, these monospecific collections commonly yield excellent three-dimensionally preserved specimens that can be isolated from their matrix and studied. In particular, the large number of well-preserved specimens allows for accurate evaluations of intra-specific variation and reliable descriptions of taxa that are generally known from flattened or otherwise distorted material. Additionally, these graptolite collections can provide important biostratigraphic ties between disparate facies-shallow mid-continental limestones and the deeper-water black shales characteristic of continental margins.

In this study, we recovered three-dimensionally preserved graptolite specimens from four collections of Middle Ordovician limestones made in the eastern and central United States. All four collections yielded mono-specific assemblages of specimens that belong to the genus Amplexograptus. Specimens isolated from the Lebanon Limestone of Tennessee are particularly noteworthy as they are referable to Amplexograptus perexcavatus (Lapworth) the poorly known type species of Amplexograptus. The presence of three-dimensional graptolites in the Lebanon Limestone was previously mentioned in the literature (Hofstetter, 1965; Conkin and Conkin, 1992), but the specimens were not described.

Two other collections, from the Upper Bromide Formation in Oklahoma and the Mifflin Member of the Platteville Formation in Illinois, yielded specimens of A. maxwelli (Decker). Our last sample, from the Kope Formation in Kentucky, yielded specimens of A. praetypicalis Riva.

The purpose of this paper is to re-describe A. perexcavatus based on well preserved three-dimensional material, to quantitatively compare the morphology of A. perexcavatus to the better known species of Amplexograptus found in our other samples, and to discuss the biostratigraphic significance of these samples. The complete morphometric data set can be obtained upon request from the senior author.

\section{SYSTEMATIC PALEONTOLOGY}

Superfamily DiPLOGRAPTACEA Lapworth, 1873 Family ORTHOGRAPTIDAE Mitchell, 1987

Genus AMPLEXOGRAPTUS Elles and Wood, 1907

Type species (by original designation).-Diplograptus perexcavatus Lapworth (1876, pl. 2, fig. 38).

Discussion.-The type species of Amplexograptus, A. perexcavatus, is known only from poorly preserved flattened specimens and has had a rather confusing history. Both Lapworth (1880) and Elles and Wood (1907) included illustrations of two distinct taxa in their descriptions of $A$. perexcavatus. Bulman (1962) rectified these errors by separating the specimens figured by Elles and Wood into two taxa, A. perexcavatus and a new species, A. fallax.
Unfortunately, Bulman's (1962) drawings of A. perexcavatus do not clearly illustrate the details of proximal end morphology, and several subsequent workers mistook an anti-virgellar spine for a theca $1^{2}$ spine (see for example Hughes, 1989, p. 58).

Mitchell (1987) revised Amplexograptus by restricting it to taxa that possessed a pattern $\mathrm{G}$ primordial astogeny. Although he did not figure any specimens, Mitchell (1987) noted that A. perexcavatus appeared to have a pattern $\mathrm{C}$ primordial astogeny and suggested suppressing $A$. perexcavatus and making $A$. fallax the genotype. A re-examination of the type material (Fig. 1) shows that A. perexcavatus clearly has a pattern $\mathrm{G}$ primordial astogeny and should remain the type species of Amplexograptus (Mitchell, personal commun., 2000).

Except for Bulman's (1962) revision, which figured Elles and Wood's original specimens, no unambiguous figures or descriptions of $A$. perexcavatus exist in the graptolite literature. Berry (1960, p. 86, pl. 16, figs. 8, 13) figured and described a poorly preserved distal fragment from the Woods Hollow Shale (Marathon Region, West Texas) as Amplexograptus cf. A. perexcavatus, and Obut and Sobolevskaya (1964, p. 64, pl. xiii, fig. 5) figured an unrecognizable specimen. Chen et al. (2000, p. 291, fig. 5.14, 5.21) figured two specimens as $A$. perexcavatus, but the illustrations of these specimens lacked anti-virgellar spines, which are characteristic of a pattern $\mathrm{G}$ primordial astogeny. Either A. perexcavatus is a rare species, or graptolite workers have been hesitant to refer specimens to this rather poorly understood taxon. A revised description of this species based on three-dimensionally preserved material is provided below.

\section{AMPLEXOGRAPTUS PEREXCAVATUS Lapworth, 1876} Figures 1.1-1.8, 2.1-2.7, 3.1, 3.3.

Diplograptus perexcavatus LAPWORTH, 1876, pl. 2, fig. 38; 1880, p. 167, pl. V, fig. 25a, b,? c, f. non 25d, e.

Climacograptus per-excavatus LAPWORTH, 1877, p. 140, pl. 6, fig. 35a, b. Amplexograptus perexcavatus (Lapworth). ELLES AND WoOD, 1907, $\mathrm{p}$ 267, text-fig. 184c, pl. xxxi, fig. $15 \mathrm{a}$, b, c. non text fig. 184a, b, d, pl. xxxi, fig. 15d; Bulman, 1962, p. 460, text-fig. 1a, b, c, d.

??Amplexograptus cf. A. perexcavatus (Lapworth). BERRY, 1960, p. 86 pl. 16, figs. 8, 13 .

??Amplexograptus perexcavatus (Lapworth). OBUT AND SOBOLEVSKAYA, 1964, p. 64, pl. xiii, fig. 5; Chen Xu, Ni Yu-Nan, Mitchell, QiaO Xin-Dong, ANd Zhan Shi-GaO, 2000, p. 291, fig. 5.14, 5.21.

Diplograptus cf. D. foliacens (Lapworth). ConKIN AND ConKIN, 1992, frontispiece, pl. 10, fig. a-f.

Diagnosis.-Amplexograptus with aseptate, rapidly widening rhabdosome; thecae with very short supragenicular walls and low apertural lappets; apertural excavations deep, long, semi-circular.

Description.-Aseptate rhabdosomes widen rapidly from a proximal width of $0.67-0.83 \mathrm{~mm}$ (avg. $=0.73, \mathrm{SD}=0.044)$ to an average of $1.76 \mathrm{~mm}$ at the tenth thecal pair $(\mathrm{SD}=0.226)$. Long specimens have distal widths greater than $2.0 \mathrm{~mm}$. The longest colonies isolated are $1.1 \mathrm{~cm}$ long and contain 18 thecal pairs. Much longer specimens (up to $3 \mathrm{~cm}$ ) occur on unprocessed slabs. Primordial astogeny follows pattern G of Mitchell (1987). Theca 


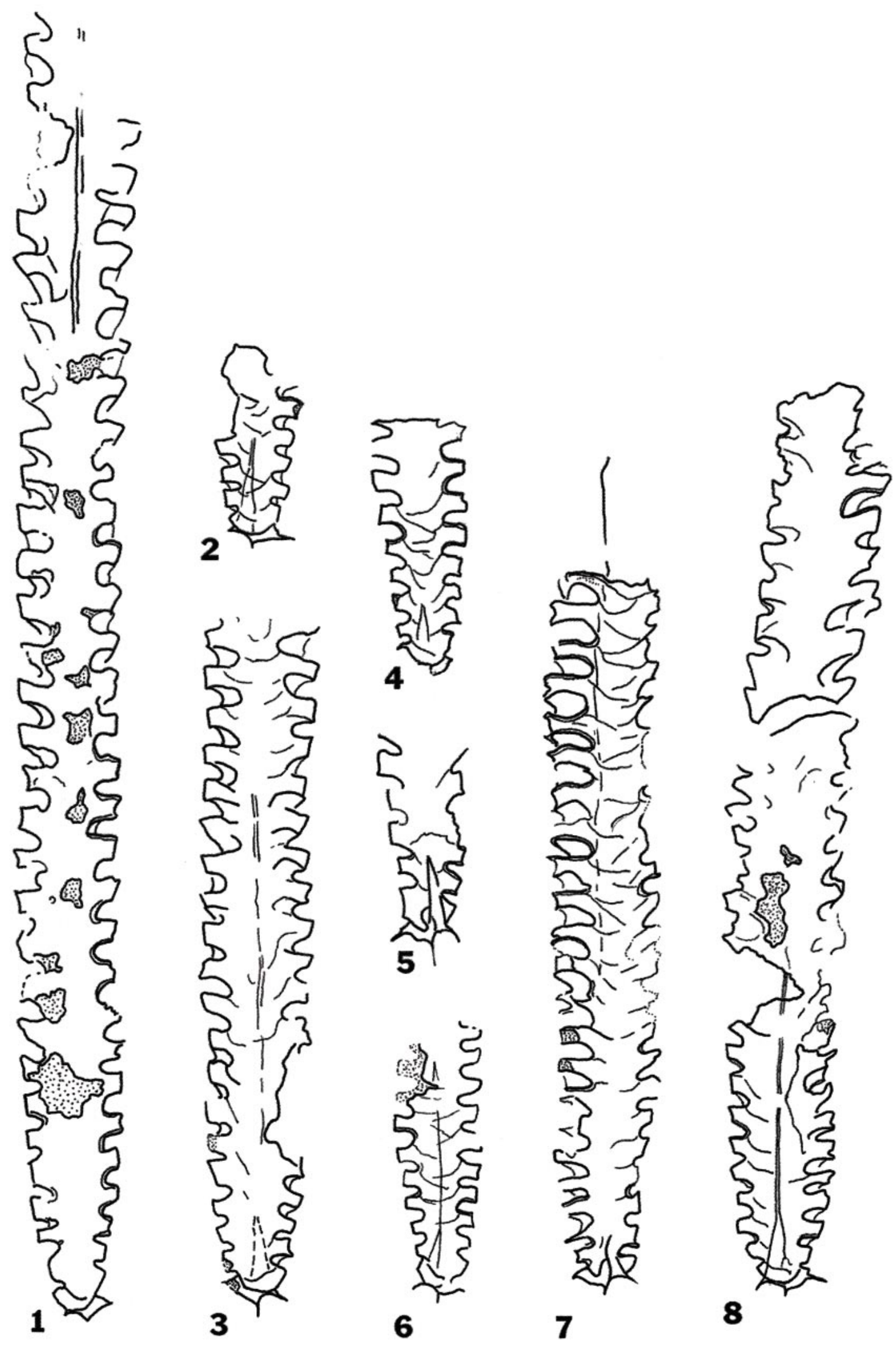

FIGURE 1-Type specimens of Amplexograptus perexcavatus Lapworth. 1, Specimen no.1030 on slab BU 1297, distal portion previously figured by Bulman (1962, text-fig. 1d); 2-6, unlabeled specimens on slab BU 1297; 7, specimen BU 1297b on counterpart of 1297, previously figured by Bulman (1962, text-fig. 1c); 8, BU 1297a, neotype of A. perexcavatus, proximal portion previously figured by Bulman (1962, text-fig. 1a). All $\times 7.5$. Drawings made and provided by C. E. Mitchell. BU $=$ Birmingham University. 

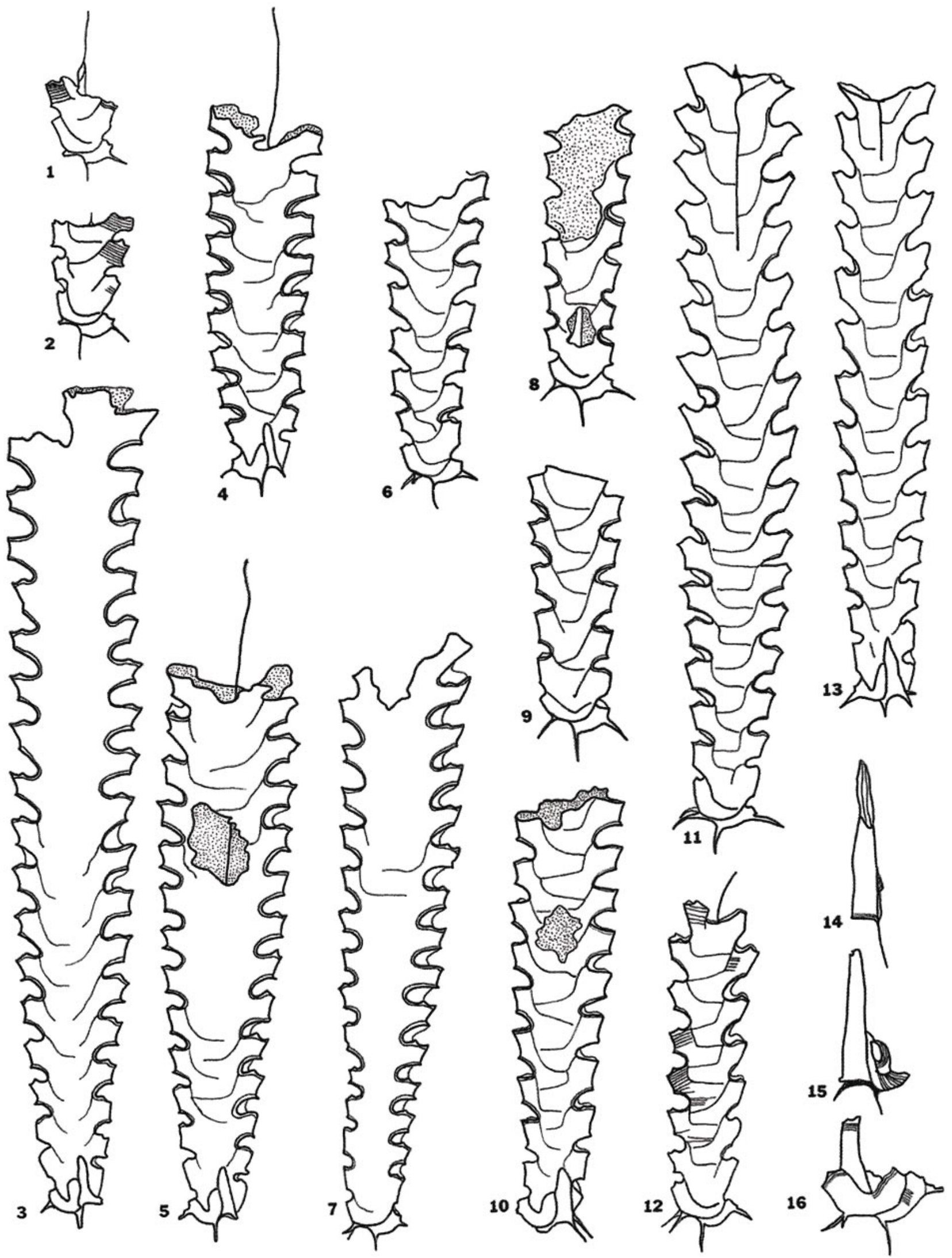

FIGURE 2-Camera lucida drawings of three-dimensionally preserved Amplexograptus specimens. 1-7, Amplexograptus perexcavatus from the Lebanon Limestone $(\times 14)$, MCZ 115911-115917; 8-10, Amplexograptus praetypicalis from the Pt. Pleasant Member of the Kope Formation $(\times 14)$, MCZ 115918-115920; 11-16, Amplexograptus maxwelli from the Bromide Formation (11-13, ×14; 14-16, ×20), MCZ 115921-115926. MCZ = Museum of Comparative Zoology, Harvard University. 

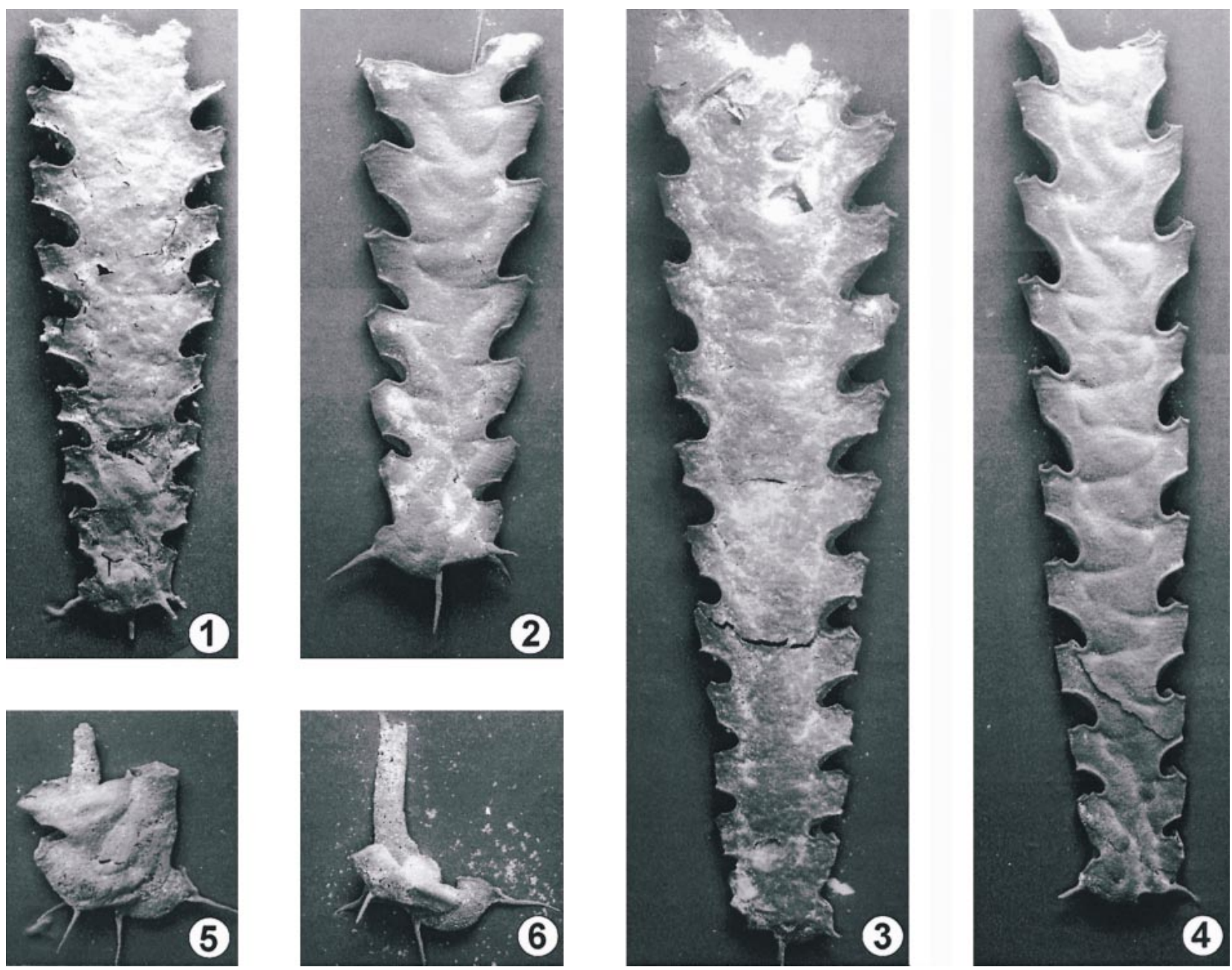

FIGURE 3-Scanning electron microscope photographs of Amplexograptus perexcavatus and A. maxwelli. 1, 3, Amplexograptus perexcavatus ( $\times 19)$, MCZ 115927, 115928; 2, 4-6, Amplexograptus maxwelli $(2, \times 19 ; 4, \times 17 ; 5,6, \times 25)$, MCZ 115929-115932. Compare the colony width, supragenicular wall height, and aperture shape in similar size rhabdosomes of A. perexcavatus and A. maxwelli.

$1^{1}$ bears a short mesial to sub-apertural spine; subsequent thecae have distinct but low apertural lappets.

Thecae have very short supragenicular walls $(0.26-0.28 \mathrm{~mm}$ proximally to $0.3 \mathrm{~mm}$ distally), and deep, high semi-circular apertures. Thecal apertures are slightly inverted, and strengthened by a selvage that extends around the infragenicular wall, forming a short genicular flange. Distally, thecal apertures are up to $1.5 \times$ higher than the supragenicular walls, which are mildly concave, and nearly parallel to the rhabdosome axis.

Type.-Neotype, BU1297, from the Upper Glenkiln Shales, Kirkmichael Burn, Scotland.

Other material examined.- Over one hundred three-dimensionally preserved specimens from the Lebanon Limestone. Most specimens are mature colonies although a few growth stages were also obtained.

Occurrence.-Our specimens were collected from a weathered outcrop of the Lebanon Limestone along U.S. Highway 231, 2.2 mi north of the Rutherford-Bedford county line, and $11.8 \mathrm{mi}$ south of Murphreesboro, Tennessee. This locality was first described by Hofstetter (1965). The three-dimensional specimens are common in a $0.3 \mathrm{~m}$ interval near the base of the upper Lebanon Limestone (Conkin and Conkin, 1992). This interval is $0.7 \mathrm{~m}$ above a massive limestone unit in the Middle Lebanon, and is referred to as the Diplograptus cf. D. foliacens Zone by Conkin and Conkin (1992).

The type specimens of $A$. perexcavatus are from the Upper Glenkiln Shales at Kirkmichael Burn in Scotland, a unit assigned to the $C$. peltifer Zone (=lower Diplograptus foliaceous Zone) by Elles and Wood (1907). The Lebanon Limestone contains conodonts of the Belodina compressa Zone (Sweet, 1984) and comprises the M3 depositional sequence of Holland and Patzkowsky (1998). The correlation of the C. peltifer graptolite Zone with the $B$. compressa conodont Zone agrees completely with the graptolite/conodont zonal ties established by Bergström (1986).

Discussion.-The most distinguishing aspects of $A$. perexcavatus are the very short supragenicular walls and large apertural excavations, hence the trivial name perexcavatus. The morphology of our specimens is very similar to the type material of $A$. perexcavatus (Fig. 1). The main differences are slightly deeper apertural excavations and more subtle lappets in the type specimens. These differences are likely a consequence of deformation during preservation. The type specimens are flattened films and several are sub-scalariform (e.g., Fig. 1.7, 1.8), an orientation that tends to accentuate the size of the thecal apertures.

Amplexograptus perexcavatus is easily differentiated from $A$. maxwelli, which occurs in rocks of similar age. It has shorter 


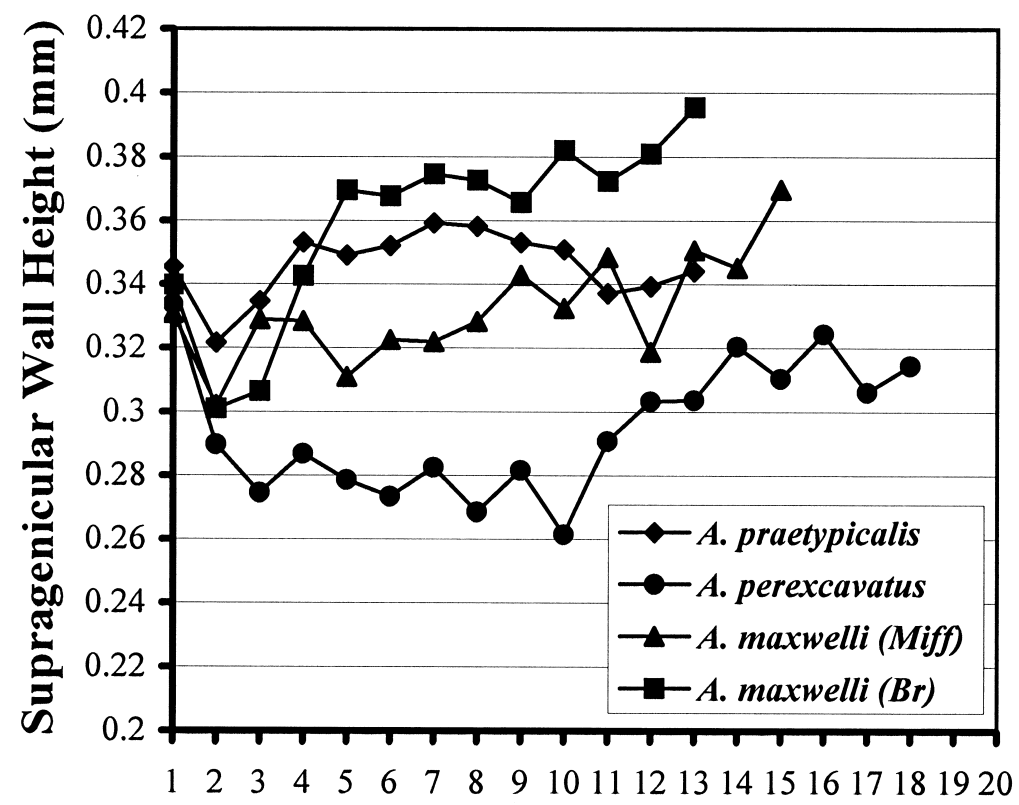

\section{Theca Number}

FigURE 4-Bivariate plot of average supra-genicular wall height vs. theca number in species of Amplexograptus. Thecae are numbered consecutively through the tenth thecal pair. Note the much shorter supra-genicular walls in A. perexcavatus.

supra-genicular walls that remain nearly parallel to the rhabdosome axis, less inverted thecal apertures, and a more rapidly widening aseptate rhabdosome (compare Fig. 2.3-2.7 with 2.11-2.13, and Fig. 3.1, 3.3 with 3.2, 3.4). Amplexograptus perexcavatus can be differentiated from A. praetypicalis by it's shorter supra-genicular walls, more strongly developed lappets, and more rapidly widening rhabdosome. Comparisons of average supragenicular wall heights and average rate of rhabdosomal widening in $A$. perexcavatus, A. maxwelli, and A. praetypicalis are shown in Figures 4 and 5.

\section{AMPLEXOGRAPTUS MAXWELLI Decker, 1935}

Figures 3.11-3.16, 4.2, 4.4-4.6

Diplograptus (Amplexograptus) maxwelli DECKER, 1935, p. 242, pl. 1, figs. 1-7, 1a-6a; DECKER AND FREDERICKSON 1941, p. 157, pl. 27, figs. 1-15; RUEDEMANN 1945, p. 413, pl. 70, figs. 33-39.

Amplexograptus maxwelli (Decker). FinNey, 1986, p. 453, pl. 1, fig. 3f, g; RIVA, 1987, p. 925, figs. 1a, b, 5a.

Amplexograptus maxwelli maxwelli (Decker). CHEN XU, Ni YU-NAN, Mitchell, Qiao Xin-Dong, AND Zhan Shi-Gao, 2000, p. 291, fig. $5.14,5.21$. See for full synonymy.

Material examined.-Hundreds of three-dimensionally preserved specimens from the Bromide Formation in Oklahoma and Mifflin Formation in Illinois.

Occurrence.-The Oklahoma specimens were collected from the Pooleville Limestone Member of the Bromide Formation, 8 $\mathrm{m}$ below the contact with the overlying Viola Springs Formation at an abandoned quarry near the north end of Criner Hills (SW1/4, SE1/4, sec. 9, T 5S, R 1E, Carter County; Decker, 1935, and Finney, 1988). The Illinois collection was made from loose blocks of the Mifflin Formation at a small quarry $2.4 \mathrm{~km}$ east of Lee Center, Lee Co., Illinois (SE1/4, SW1/4, sec. 9, T 20N, R 11E. Mendota Quad.; Willman and Kolata, 1978). The Illinois sample was generously provided by Mr. John A. Catalani of Downers Grove, Illinois.

Amplexograptus maxwelli also occurs in the Mount Merino Shale ("Normanskill") of New York State (Goldman and Barrett,
2000), and the Balclatchie Group, Glenkiln, and Lower Hartfell Shales of southern Scotland (Bulman, 1945, 1962; Williams, 1994). These units are assigned to the $C$. peltifer and $C$. wilsoni zones (=Diplograptus foliaceous Zone) (Elles and Wood, 1907; Williams, 1994). The presence of A. maxwelli in the upper Bromide and Mifflin formations suggests a similar graptolite age for those units.

The Mifflin and the upper Bromide Formations contains conodonts of the Phragmodus undatus and Plectodina aculeata zones, respectively (Sweet, 1984). The correlation of the D. foliaceous graptolite Zone with the $P$. undatus and $P$. aculeata conodont zones agrees with the graptolite/conodont zonal ties established by Bergström (1986).

Discussion.-Amplexograptus maxwelli has been thoroughly described and illustrated in the literature (e.g., Decker, 1935; Decker and Frederickson, 1941; Walker, 1953; Riva, 1987). Finney (1986) noted that the type specimens of A. leptotheca (Bulman) were virtually identical to specimens of $A$. maxwelli (Decker) from Oklahoma, and regarded the former as a junior synonym of the latter. Riva (1987) and Hughes (1989) listed A. fallax Bulman as a junior synonym of $A$. leptotheca.

\section{AMPLEXOGRAPTUS PRAETYPICALIS Riva, 1987}

Figure 3.8-3.10.

Amplexograptus praetypicalis RIVA 1987, p. 928, figs. 2a-g, 3a-q, 4a-c, $5 \mathrm{c}, \mathrm{d}, 7 \mathrm{a}$ in part.

Occurrence.-Our specimens of A. praetypicalis are part of the Dyer Collection, Museum of Comparative Zoology, Harvard University. The sample was collected at Foster's Landing, Kentucky. Bergström and Mitchell (1986) concluded that the sample was probably collected from either the Pt. Pleasant Formation or the lower Kope Formation. Amplexograptus praetypicalis is a key index species for the lower Climacograptus (D.) spiniferus Zone (Riva, 1987).

Discussion.-Amplexograptus praetypicalis was fully described by Riva (1987). Our specimens agree well with Riva's 


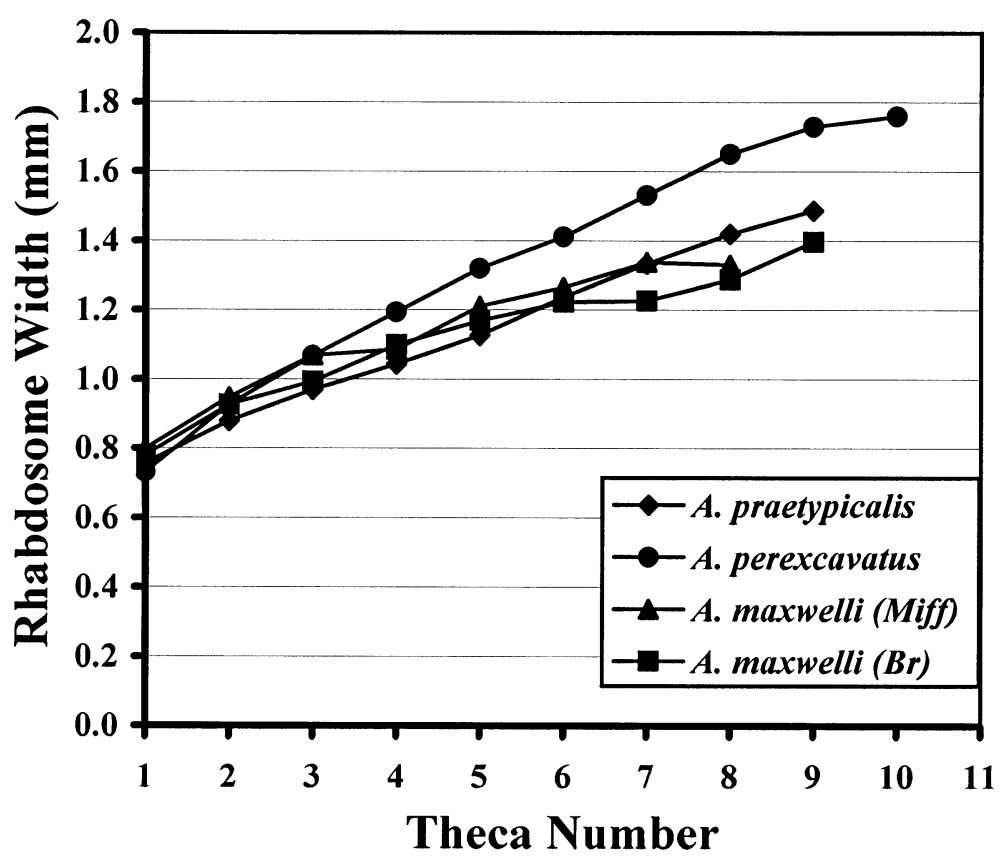

FIGURE 5-Bivariate plot of average rhabdosome width vs. theca number in species of Amplexograptus. Thecae are numbered consecutively through the sixth thecal pair. Note the greater rate of widening in A. perexcavatus.

description. Amplexograptus praetypicalis is similar to A. maxwelli in it's overall dimensions (Figs. 4 and 5), but can be differentiated from the latter species by it's much lower lappets, less inverted thecal apertures, and lack of a median septum. Amplexograptus praetypicalis can be differentiated from A. perexcavatus by its longer thecae, shorter apertures and narrower rhabdosome.

\section{ACKNOWLEDGMENTS}

We would like to thank C. E. Mitchell and J. A. Catalani for providing specimens, and S. C. Finney, S. M. Bergström, and J. A. Catalani for outcrop information and assistance in the field. We are also grateful to S. J. Wright for assistance with scanning electron microscope photography.

\section{REFERENCES}

BERGSTRÖM, S. M. 1986. Biostratigraphic integration of Ordovician graptolite and conodont zones-a regional review, p. 61-78. In C. P. Hughes and R. B. Rickards (eds.), Paleoecology and Biostratigraphy of Graptolites. Geological Society Special Publication 20, Blackwell Scientific Publications, Oxford.

BERRY, W. B. N. 1960. Graptolite faunas of the Marathon Region, West Texas. University of Texas Publication 6005,179 p., 20 pls.

Bulman, O. M. B. 1945-1947. Monograph of the Caradoc (Balclatchie) graptolites from the limestones in Laggan Burn, Ayrshire. Monograph of the Palaeontographical Society, 78 p., 10 pls.

Bulman, O. M. B. 1962. On the genus Amplexograptus Lapworth, Elles and Wood. Geological Magazine, 99:459-467.

Chen Xu, Ni Yu-Nan, Charles E. Mitchell, Qiao Xin-Dong, and ZHAN SHI-GAO. 2000. Graptolites from the Qilang and Yingan Formations, (Caradoc, Ordovician) of Kalpin, Western Tarim, Xinjiang, China. Journal of Paleontology, 74:282-300.

ConkIn, J. E., AND B. M. ConkIN. 1992. Paleozoic metabentonites of North America, Pt. 3, New Ordovician metabentonites from Kentucky and Tennessee. University of Louisville Studies in Paleontology and Stratigraphy, 20, 32 p., 11 pls.

CROWTHER, P. R. 1981. The fine structure of graptolite periderm. Special Papers in Palaeontology, 26:1-119.

DECKER, C. E. 1935. The graptolites of the Simpson Group. Proceedings of the National Academy of Sciences, 21:239-243.

Decker, C. E., And E. A. Frederickson. 1941. A new graptolite horizon in Wisconsin. Journal of Paleontology, 15:157-159.
Elles, G. L., AND E. M. R. WoOD. 1910-1918. A monograph of British graptolites. Monograph of the Palaeontographical Society, clxxi +539 p., 52 pls.

FINNEY, S. C. 1986. Graptolite biofacies and correlation of eustatic, subsidence, and tectonic events in the Middle to Upper Ordovician of North America. Palaios, 1:435-461.

FinNEY, S. C. 1988. Middle Ordovician strata of the Arbuckle and Ouachita mountains, Oklahoma; contrasting lithofacies and biofacies deposited in southern Oklahoma Aulacogen and Ouachita geosyncline. Geological Society of America Centennial Field Guide-South Central Section, p. 171-176.

Goldman, D., AND K. T. BARRETT. 2000. Working toward a standard Upper Ordovician graptolite zonation: correlation of the Mt. Merino and Utica shales in New York State. Geological Society of America Abstracts with Programs, 32(4):A-15.

Hofstetter, O. B. 1965. Middle Ordovician graptolites from the Lebanon Limestone, Central Tennessee. Journal of Paleontology, 39:287288.

Holland, S. M., AND M. E. PATZKowsky. 1998. Sequence stratigraphy and relative sea-level history of the Middle and Upper Ordovician of the Nashville Dome, Tennessee. Journal of Sedimentary Research, 68: 684-699.

Hughes, R. A. 1989. Llandeilo and Caradoc graptolites of the Builth and Shelve inliers. Monograph of the Palaeontographical Society, 577:189.

LAPWORTH, C. 1873. On an improved classification of the Rhabdophora. Geological Magazine, 10:500-504, 555-560.

LAPWORTH, C. 1876. The Silurian System in the South of Scotland, p. 1-28. In J. Armstrong, J. Young, and D. Robertson (eds.), Catalogue of Western Scottish Fossils. Blackie and Son, Glasgow.

Lapworth, C. 1877. On the graptolites of County Down. Proceedings of the Belfast Naturalists' Field Club-appendix IV, p. 125-144, pls. v-vii.

LAPWORTH, C. 1880. On new British graptolites. Annals and Magazine of Natural History, (Series 5)5:149-177, 2 pls.

Mitchell, C. E. 1987. Evolution and phylogenetic classification of the Diplograptacea. Palaeontology, 30:353-405.

Obut, A. M., AND R. F. Sobelevskaya. 1964. Ordovician graptolites of Taimyr. Akad. Nauk SSSR Sibirskoye otdeleniye, Inst. Geologii I Geofiziki-Nauchno-Issled. Inst. Geologii Artiki, 86 p., 16 pl. (In Russian) RIVA, J. 1987. The graptolite Amplexograptus praetypicalis n. sp. and 
the origin of the typicalis group. Canadian Journal of Earth Science, 24:924-933.

RuedemAnN, R. 1945. Graptolites of North America. Geological Society of America Memoir 19, 652 p., 92 pls.

StRachan, I. 1986. The Ordovician graptolites of the Shelve District, Shropshire. Bulletin of the British Museum of Natural History (Geology), 40:1-58.

SwEET, W. C. 1984. Graphic correlation of Upper Middle and Upper Ordovician rocks, North American Midcontinent Province, U.S.A., p. 23-36. In D. L. Bruton (ed.), Aspects of the Ordovician System. Paleontological Contributions from the University of Oslo, 295.
Walker, M. 1953. The development of a diplograptid from the Platteville Limestone. Geological Magazine, 90:1-16.

WiLLIAMS, S. H. 1994. Revision and definition of the $C$. wilsoni graptolite Zones (Middle Ordovician) of southern Scotland. Transactions of the Royal Society of Edinborough, Earth Sciences, 85:143-157.

Willman, H. B., AND D. R. Kolata. 1978. The Platteville and Galena Groups in Northern Illinois. Illinois State Geological Survey Circular $502,75 \mathrm{p}$.

ACCEPTED 20 SEPTEMBER 2001 